\title{
GALERI EDUKASI PLASTIK DENGAN PENDEKATAN METODE PERANCANGAN PLASTIS
}

\author{
Wandy Halim ${ }^{1)}$, Franky Liauw ${ }^{2)}$ \\ 1)Program Studi S1 Arsitektur, Fakultas Teknik, Universitas Tarumanagara, wandy.Imzl@gmailcom \\ ${ }^{2)}$ Program Studi S1 Arsitektur, Fakultas Teknik, Universitas Tarumanagara, frankyl@ft.untar.ac.id
}

Masuk: 02-07-2021, revisi: 13-08-2021, diterima untuk diterbitkan: 23-10-2021

\begin{abstract}
Abstrak
Dalam kehidupan manusia di dunia, permasalahan sampah merupakan permasalahan yang pasti akan dialami, dan tidak akan pernah ada habisnya. Permasalahan sampah ini disebabkan oleh tingginya perilaku konsumtif manusia. Sampah plastik merupakan salah satu masalah sampah yang perlu mendapat perhatian yang serius karena masalah sampah plastik ini sudah menjadi masalah lingkungan skala global. Untuk dapat mengatasi sampah plastik yang besar ini, dibutuhkan kecepatan dalam menyerap sampah plastik dan pemanfaatannya dalam bidang pengolahan karena sampah plastik merupakan sampah yang sangat sulit untuk terurai. Di Indonesia, kesadaran dan pengetahuan masyarakat akan sampah plastik masih sangatlah kurang, sehingga pengolahan sampah plastik ini masih belum maksimal. RE-Plastic Gallery merupakan fasilitas galeri edukasi plastik yang menerapkan metode perancangan plastis. Metode perancangan plastis ini mengambil sifat dari plastik itu sendiri yaitu plastis yang berarti mudah untuk dibentuk. Dengan sifat plastis ini, akan diterapkan bentuk yang plastis, ruang yang plastis, dan kegiatan yang plastis pada desain galeri edukasi. Pandangan masyarakat mengenai sampah plastik akan diubah melalui kegiatan pameran yang interaktif, mulai dari pameran mengenai apa itu plastik, dampak plastik ke lingkungan, karya-karya seni plastik, produk-produk plastik, hingga hasil-hasil penelitian mengenai plastik yang bertujuan untuk memerangi sampah plastik. Dengan begitu masyarakat yang pada awalnya membuang sampah plastik akan memburu sampah plastik, karena tersadarkan bahwa plastik itu sebenarnya bermanfaat, berharga, menguntungkan, dan juga menyenangkan.
\end{abstract}

Kata kunci: galeri edukasi; metode perancangan plastis; plastik

\begin{abstract}
In human life, waste is a problem that will inevitably become, and will never end. This waste problem is caused by high human consumptive behavior. Plastic waste is one of the waste problems that need serious attention because the problem of plastic waste has become a global environmental problem. To be able to overcome this large plastic waste, it takes speed in absorbing plastic waste and its use in the field of processing because plastic waste is waste that is very difficult to decompose. In Indonesia, public awareness and knowledge of plastic waste are still very lacking, so that the processing of plastic waste is still not optimal. RE-Plastic Gallery is a plastic educational gallery facility that applies the plastis design method. This plastis design method takes the nature of the plastic itself, namely plastis which means it is easy to form. With this plastis nature, plastis forms, plastis spaces, and plastis activities will be applied to the design of educational galleries. People's view of plastic waste will be changed through interactive exhibition activities, ranging from exhibitions on what plastic is, the impact of plastic on the environment, plastic artworks, plastic products, to research results on plastics aimed at fighting plastic waste. That way, people who initially dispose of plastic waste will hunt for plastic waste because they are aware that plastic is useful, valuable, profitable, and also fun.
\end{abstract}

Keywords: educational gallery; plastic; plastis design method 


\section{PENDAHULUAN}

Permasalahan sampah merupakan masalah yang tidak akan pernah ada habisnya. Sampah plastik merupakan salah satu masalah yang perlu mendapat perhatian yang serius karena masalah sampah plastik ini sudah menjadi masalah lingkungan skala global. Volume sampah plastik dari tahun ke tahun terus meningkat seiring dengan laju pertumbuhan jumlah penduduk. Ketua umum Indonesia Solid Waste Association (InSWA), Sri Bebassari mengatakan dari waktu ke waktu, penggunaan plastik meningkat secara signifikan melampaui penggunaan bungkus berbahan kertas. "Butuh waktu ratusan, bahkan ribuan tahun agar bisa terurai, maka plastik dianggap sebagai bahan yang sangat merusak lingkungan" (Prasetyo, 2014).

Pengelolaan sampah plastik merupakan cara meminimalkan pencemaran yang diakibatkan oleh plastik yang selama ini di konsumsi oleh masyarakat. Pengelolaan sampah plastik dilakukan sedemikian rupa untuk mengurangi sampah plastik yang mencemari lingkungan sehingga tidak mengganggu kesehatan manusia ataupun merusak ekologi lingkungan. Dalam menyerap sampah plastik, dibutuhkan keikut sertaan masyarakat dalam mempermudah proses penyerapan plastik. Namun pada saat ini sampah plastik dipandang sebelah mata oleh masyarakat karena sampah dianggap tidak berguna, kotor, menjijikan, dan mencemari lingkungan sehingga ditakuti. Hal ini disebabkan oleh kurangnya pengetahuan yang masyarakat miliki mengenai cara menangani sampah plastik. Padahal sampah plastik memiliki nilai jual dan nilai ekonomis yang cukup tinggi apabila diolah kembali menjadi berbagai produk berbahan plastik.

Dari permasalahan tersebut, terdapat rumusan masalah utama yaitu bagaimana arsitektur dapat berperan dalam menyadarkan atau mengubah pandangan masyarakat terhadap sampah plastik dalam upaya memerangi sampah plastik. Proyek yang diusulkan adalah galeri edukasi plastik yang bertujuan untuk memerangi sampah plastik dengan menyadarkan atau mengubah pandangan masyarakat mengenai sampah plastik, dari sampah plastik yang dianggap sampah yang mencemari lingkungan menjadi plastik yang ramah lingkungan dan tidak ditakuti lagi. Galeri edukasi plastik ini akan menerapkan metode perancangan plastis yang diambil dari sifat plastik itu sendiri yaitu 'plastis' yang berarti mudah untuk dibentuk. Dengan menerapkan metode perancangan plastis pada galeri edukasi plastik ini diharapkan masyarakat yang pada awalnya membuang sampah plastik akan memburu sampah plastik, karena tersadarkan bahwa plastik itu sebenarnya bermanfaat, menguntungkan, dan juga menyenangkan. Upaya masyarakat dalam memburu plastik ini menjadi kontribusi dalam memerangi sampah plastik dan menciptakan lingkungan yang bersih dan berkelanjutan.

\section{KAJIAN LITERATUR}

\section{Ekologi}

Menurut KKBI, Ekologi / eko.lo.gi / ékologi adalah ilmu tentang hubungan timbal balik antara makhluk hidup dan (kondisi) alam sekitarnya (lingkungannya). Dalam ilmu lingkungan, ekologi dijadikan sebagai ilmu dasar untuk memahamiinteraksi di dalam lingkungan. Dalam ekologi terdapat hirarki yang dimulai dari tingkatan terkecil yaitu molekul, sel, jaringan, organ, sistem organ, individu, populasi, komunitas, ekosistem, dan biosfer. Terdapat komponen biotik atau hidup dan abiotik atau non hidup dalam ekologi dan seluruh komponen ini saling berinteraksi (Adiwobowo, 2007).

Sistem ekologi terbentuk dari kesatuan dan interaksi antarkomponen penyusun ekosistem yang saling berhubungan satu sama lain. Peran ekologi adalah mempertanyakan, menyelidiki, dan memahami bagaimana alam bekerja secara mendasar. (Steiner, 2016) Ekologi memberitahukan keberadaan makhluk hidup dan kebutuhannya dalam sistem kehidupan yang berbentuk habitat. 
Ekologi juga menjelaskan cara makhluk hidup dapat hidup bersama, bertahan dan beradaptasi di lingkungan yang sama dengan spesies lain dengan berbagai perubahannya. (Jørgensen, 2009)

\section{Sampah dan Limbah}

Sampah merupakan material sisa yang tidak diinginkan setelah berakhirnya suatu proses. Sampah didefinisikan oleh manusia menurut derajat keterpakaiannya, dalam proses-proses alam sebenarnya tidak ada konsep sampah, yang ada hanya produk-produk yang dihasilkan setelah dan selama proses alam tersebut berlangsung. Akan tetapi karena dalam kehidupan manusia didefinisikan konsep lingkungan maka sampah dapat dibagi menurut jenis-jenisnya. (Septyan, 2019)

Limbah adalah buangan yang dihasilkan dari suatu proses produksi baik industri maupun domestik (rumah tangga). Di mana masyarakat bermukim, di sanalah berbagai jenis limbah akan dihasilkan. Ada sampah, ada air kakus (black water), dan ada air buangan dari berbagai aktivitas domestik lainnya (grey water). Limbah padat lebih dikenal sebagai sampah, yang sering kali tidak dikehendaki kehadirannya karena tidak memiliki nilai ekonomis. Dengan konsentrasi dan kuantitas tertentu, kehadiran limbah dapat berdampak negatif terhadap lingkungan terutama bagi kesehatan manusia, sehingga perlu dilakukan penanganan terhadap limbah. (Larasati, 2017)

\section{Galeri Edukasi}

Galeri adalah selasar atau tempat; dapat pula diartikan sebagai tempat yang memamerkan karya seni tiga dimensional karya seorang atau sekelompok seniman atau bisa juga didefinisikan sebagai ruangan atau gedung tempat untuk memamerkan benda atau karya seni (Pusat Bahasa Departemen Pendidikan Nasional, 2003), dan edukasi secara umum adalah suatu proses pembelajaran yang dilakukan baik secara formal maupun non formal yang bertujuan untuk mendidik, memberikan ilmu pengetahuan, serta mengembangkan potensi diri yang ada dalam diri setiap manusia, kemudian mewujudkan proses pembelajaran tersebut dengan lebih baik. Galeri edukasi adalah fasilitas pameran karya seni atau hasil dari sebuah penelitian yang bertujuan untuk memberikan ilmu pengetahuan kepada setiap pengunjung yang datang dengan edukasi informal melalui karya-karya yang dipamerkan baik secara media cetak, realia, audio, maupun audio-visual.

\section{Plastik}

Plastik adalah jenis makromolekul yang dibentuk dengan proses polimerisasi. Polimerisasi adalah proses penggabungan beberapa molekul sederhana (monomer) melalui proses kimia menjadi molekul besar (polimer atau makromolekul). Plastik terdiri dari senyawa polimer yang unsur penyusun utamanya adalah karbon dan hidrogen. Pengembangan plastik berasal dari penggunaan material alami (seperti: karet alami, "shellac") sampai ke material alami yang dimodifikasi secara kimia (seperti: permen karet, "nitrocellulose") dan akhirnya ke molekul buatan-manusia (seperti: epoxy, polyvinyl chloride, polyethylene). (Hendrastianto, 2019)

\section{Dampak Sampah Plastik Terhadap Lingkungan}

Konsumsi berlebih terhadap plastik, pun mengakibatkan jumlah sampah plastik yang besar. Karena bukan berasal dari senyawa biologis, plastik memiliki sifat sulit terdegradasi (nonbiodegradable). Plastik diperkirakan membutuhkan waktu 100 hingga 500 tahun hingga dapat terdekomposisi (terurai) dengan sempurna. Sampah kantong plastik dapat mencemari tanah, air, laut, bahkan udara. (Rahmat,2016)

Sampah plastik akan memberikan akibat, antara lain:

a. Tercemarnya tanah, air tanah dan makhluk bawah tanah.

b. Racun-racun dari partikel plastik yang masuk ke dalam tanah akan membunuh hewanhewan pengurai di dalam tanah. 
c. Plastik yang tidak dapat terurai meskipun termakan oleh binatang maupun tanaman akan menjadi racun berantai sesuai urutan rantai makanan.

d. Kantong plastik akan mengganggu jalur air yang teresap ke dalam tanah.

e. Menurunkan kesuburan tanah karena plastik juga menghalangi sirkulasi udara di dalam tanah dan ruang gerak makhluk bawah tanah yang mampu menyuburkan tanah.

f. Kantong plastik yang sukar diurai, mempunyai umur panjang, dan ringan akan mudah diterbangkan angin hingga ke laut sekalipun.

g. Hewan-hewan dapat terjerat dalam tumpukan plastik.

h. Hewan-hewan laut seperti lumba-lumba, penyu laut, dan anjing laut menganggap kantongkantong plastik tersebut makanan dan akhirnya mati karena tidak dapat mencernanya.

i. Ketika hewan mati, kantong plastik yang berada di dalam tubuhnya tetap tidak akan hancur menjadi bangkai dan dapat meracuni hewan lainnya.

j. Pembuangan sampah plastik sembarangan di sungai-sungai akan mengakibatkan pendangkalan sungai dan penyumbatan aliran sungai yang menyebabkan banjir.

\section{Metode Perancangan Plastis}

Metode perancangan plastis mengambil sifat dari plastik itu sendiri yaitu 'plastis' yang berarti bersifat mudah untuk dibentuk. Dengan sifat plastis ini, bentuk massa bangunan dibuat tidak kaku. Bentuk yang tidak kaku pada umumnya merupakan bentuk yang melengkung, dan tidak memiliki banyak siku di sisinya. Selain itu sifat plastis ini juga diterapkan pada ruangan dan kegiatan dalam galeri. Ruang yang plastis berarti ruang yang tidak kaku, artinya bentuk ruang dapat berubah, tidak tetap atau monoton. Lalu kegiatan yang plasti berarti kegiatan yang fleksibel, tidak terikat oleh tempat, dan keadaan atau situasi.

Selain penerapan sifat plastis, galeri edukasi plastik ini juga akan menggunakan material plastik pada bagian-bagian bangunan (Engelsmann, 2010) untuk mengenalkan langsung materialmaterial plastik kepada pengunjung galeri. Plastik memiliki banyak sekali jenis dan kelebihan yang dapat dimanfaatkan. Dengan penerapan material plastik pada bagian bangunan, pandangan pengunjung terhadap plastik akan dapat berubah dikarenakan material plastik juga dapat menjadi ramah terhadap lingkungan dan manusia.

\section{Plastis}

Sifat plastis dari plastik ini akan diterapkan pada desain bangunan yaitu dengan bentuk yang plastis, ruang yang plastis, dan kegiatan yang plastis.

a. Bentuk yang plastis

Menerapkan bentuk yang tidak kaku, yaitu bentuk yang melengkung, dan tidak memiliki banyak sudut siku di sisi-sisinya.

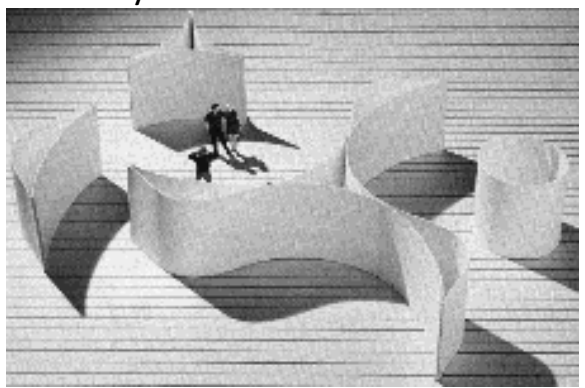

Gambar 1. Bentuk yang plastis Sumber: www.artspace.com

b. Ruang yang plastis

Ruang yang tidak kaku, artinya bentuk ruang dapat berubah, tidak tetap atau monoton. Bentuk ruang dapat menyesuaikan dengan kebutuhan. (Herman, 2013) Selain itu pengunjung dapat membentuk ruangan sesuai dengan keinginannya dengan menggunakan partisi plastik. (seperti lego) 
c. Kegiatan yang plastis

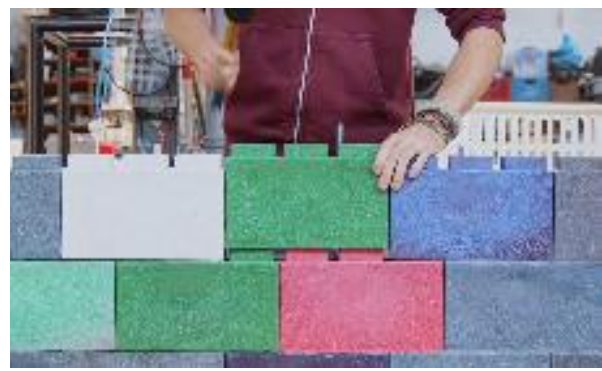

Gambar 2. Ruang yang plastis

Sumber: www.art-sheep.com

Kegiatan yang tidak terikat oleh tempat, dan keadaan atau situasi. Diterapkan pada kegiatan pameran yang bersifat aktif untuk menarik pengunjung - 'interactive gallery', jadi seluruh bagian dari bangunan dapat dimanfaatkan untuk kegiatan pameran.

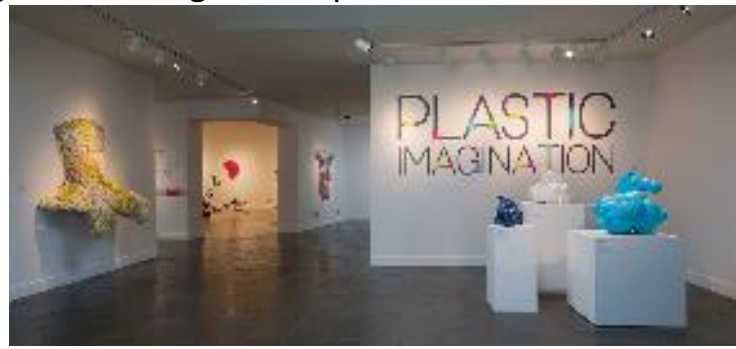

Gambar 3. Kegiatan yang plastis

Sumber: www.artspace.com

\section{METODE}

\section{Metode Pengumpulan Data}

Data diperoleh secara kualitatif dengan studi pustaka, jurnal-jurnal ilmiah, e-book, dan beritaberita yang terkait dengan teori-teori yang akan dibahas. Dengan adanya pemahaman yang didapat melalui data yang diperoleh akan meningkatkan pemahaman penulis untuk diaplikasikan sebagai dasar dalam mendukung proses perancangan, menciptakan program, dan menciptakan desain yang dapat mencapai tujuan dari proyek ini yaitu memerangi sampah plastik dengan menyadarkan atau mengubah pandangan orang terhadap sampah plastik, dari sampah plastik yang dianggap tidak berguna, kotor, menjijikan, dan mencemari lingkungan menjadi plastik yang ramah lingkungan dan tidak ditakuti lagi. Dengan demikian masyarakat yang dari awalnya membuang sampah plastik akan memburu plastik karena plastik menjadi bermanfaat, berharga, menguntungkan, dan menyenangkan.

\section{DISKUSI DAN HASIL}

\section{Material Plastik}

Material plastik memiliki kelebihan antara lain:

a. Plastik memiliki ketahanan yang melebihi beton, umur plastik dapat mencapai 30 tahun

b. Lebih ringan, namun bersifat kuat dan tidak pecah

c. Tidak mudah terbakar

d. Dapat didaur ulang

e. Memiliki daya dukung arsitektur modern

Penggunaan material plastik pada bangunan sudah ada sejak tahun 1953. Proyek pertama ini merupakan sebuah rumah karya Massaccussets Institute of Technology, US. Alasan utama proyek ini menggunakan material plastik adalah untuk menciptakan bangunan yang memiliki ketahanan yang lebih lama, perawatan yang lebih mudah, serta kemudahan dari material plastik yang mudah dibentuk, diproduksi dengan cepat, dapat didaur ulang, dan murah. (Higgin, 2012) 


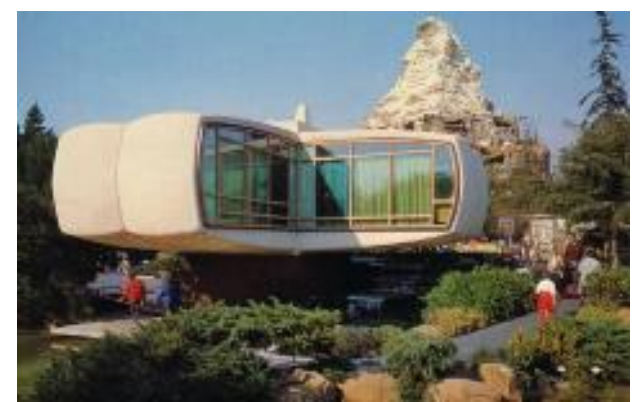

Gambar 4. Mosanto House of the Future

Sumber: www.mentalfloss.com

Pada galeri edukasi plastik ini, material plastik akan digunakan pada elemen-elemen arsitektur, mulai dari lantai, dinding, atap serta pengganti material kaca. Untuk bagian struktur bangunan tetap menggunakan material struktur beton bertulang.

\section{Penerapan Material Plastik pada Elemen Arsitektur}

Elemen Lantai

a. Plastic Tiles

Merupakan keramik berbahan dasar plastik. Dicetak dari biji plastik dengan warna dan ukuran yang dapat disesuaikan.

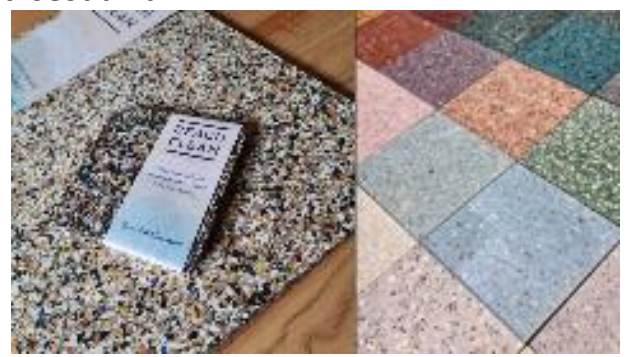

Gambar 5. Plastic Tile

Sumber: www.instructables.com

b. Plastic Paving Blocks

Merupakan paving blok hasil daur ulang plastik. Dapat digunakan pada bagian outdoor atau semi outdoor.

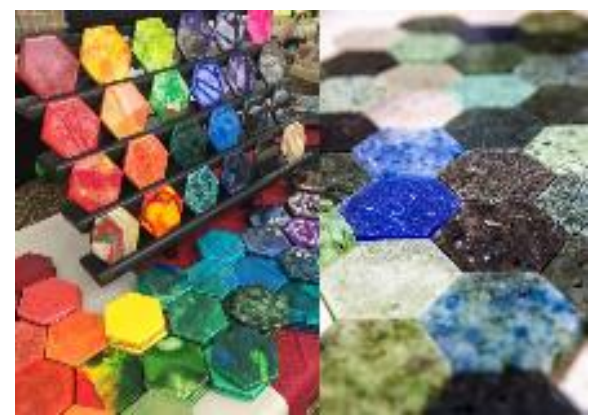

Gambar 6. Plastic Paving Block

Sumber: www.joyaplastica.com

Elemen Dinding

a. Plastic Bricks

Marupakan batu bata hasil daur ulang plastik. Bata jenis ini dapat menjadi air insulation yang baik dalam menjaga suru ruangan, selain itu bata ini memiliki daya tahan yang melebihi beton. (Azzam, 2021) 


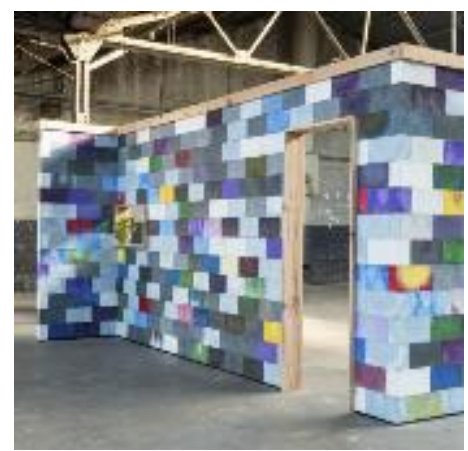

Gambar 7. Plastic Bricks

Sumber: www.preciousplastic.com

b. Plastic Sheets

Merupakan dinding partisi hasil daur ulang plastik yang memiliki ketebalan $1-5 \mathrm{~cm}$. Dinding partisi plastik ini sangat ringan dan dapat digunakan sebagai partisi, pelapis dinding, atau untuk material pintu.
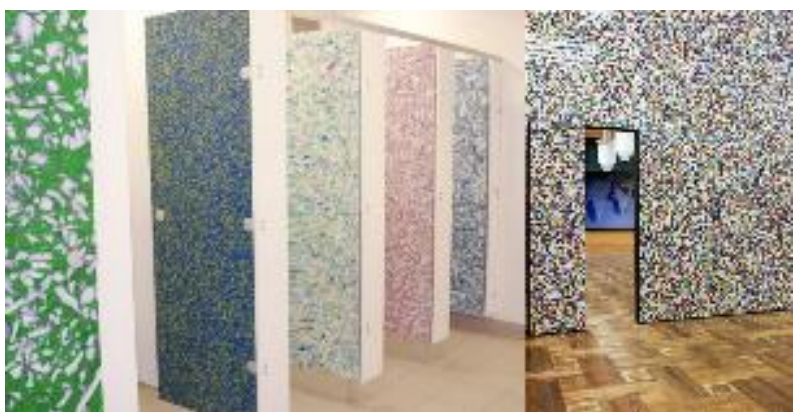

Gambar 8. Plastic Sheets

Sumber: www.instructables.com

Elemen Atap

ETFE (Ethylene Tetraflouroethylene)

Merupakan material membrane plastik generasi baru yang dapat digunakan pada bagian atap dan fassad bangunan. Memiliki ketahanan terhadap sinar UV dan cuaca, meredam suara, transmisi cahaya yang sangat baik (mencapai 95\%), dan lebih ringan dari kaca. (Richardson,2009)

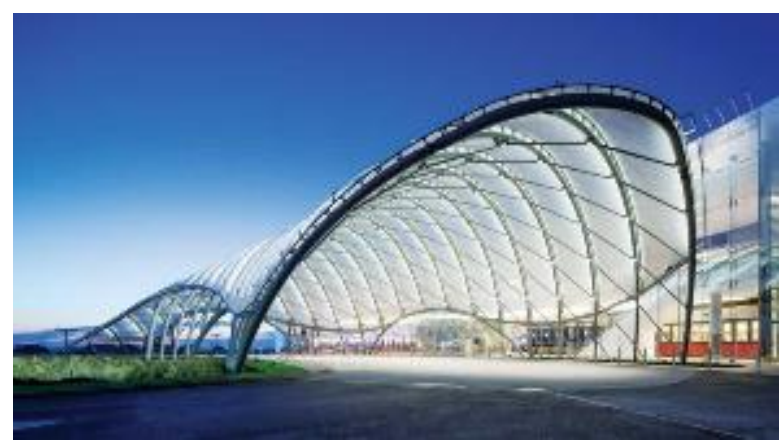

Gambar 9. Atap ETFE

Sumber: www.architen.com

Material Pengganti Kaca

Polycarbonate

Material plastik yang dapa menggantikan penggunaan kaca. Bersifat 200x lebih kuat dari kaca, dan telah diakui oleh greenship. (PT. Impact Pratama Industri, 2019) 


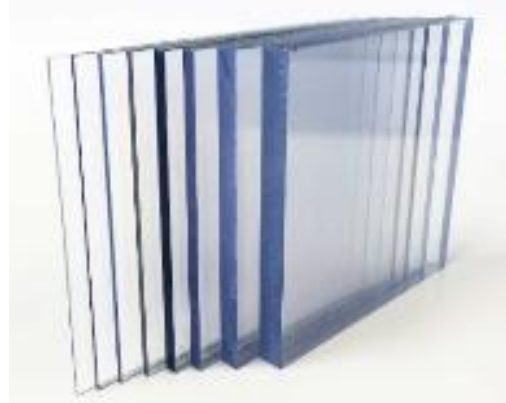

Gambar 10. Kaca Polycarbonate

Sumber: www.impack-pratama.com

\section{Pengaplikasian Metode Perancangan Plastis pada Desain Bentuk Massa}

Berdasarkan metode perancangan plastis dibuatkan pola dasar yang terbentuk dari lengkunganlengkungan dan lingkaran agar tidak tercipta bentuk yang kaku.

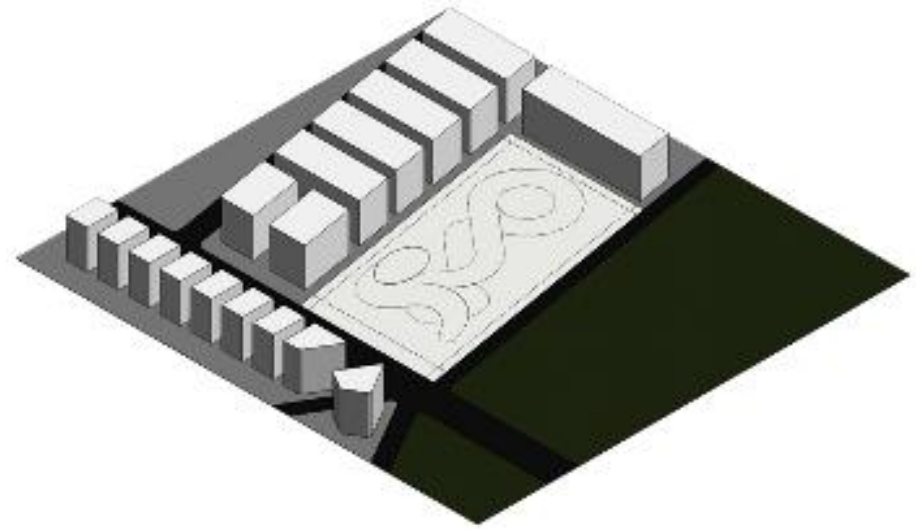

Gambar 11. Pola dasar lengkung pada tapak Sumber: Penulis, 2021

Pada bagian depan tapak bangunan dibuatkan lengkungan yang mencekung ke dalam untuk memperoleh bentuk massa bangunan yang seperti menarik orang untuk datang.

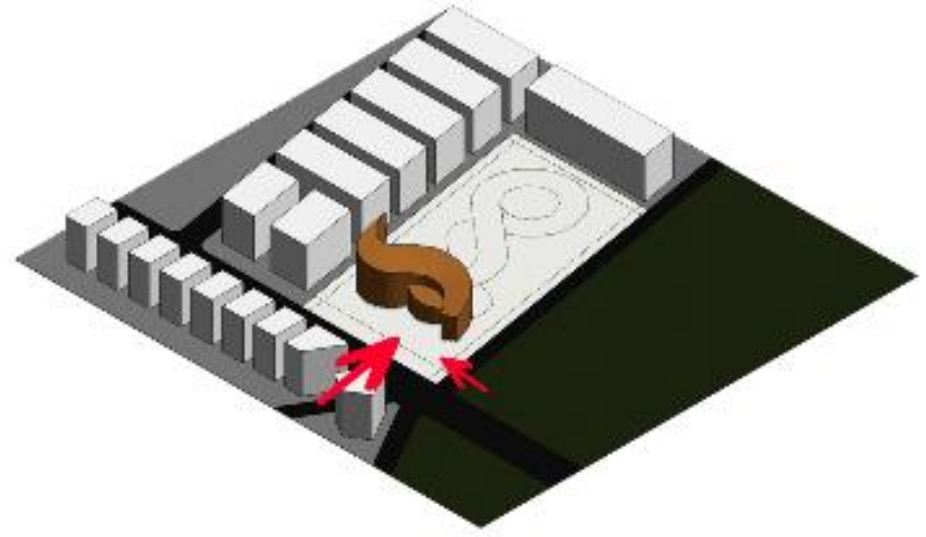

Gambar 12. Massa bangunan sisi depan Sumber: Penulis, 2021

Pada bagian belakang tapak dibuatkan massa spiral yang menghubungkan lantai atas dengan satu lantai dibawahnya. Spiral ini akan menciptakan sirkulasi yang menerus pada saat orang berkeliling pada area spiral ini. 


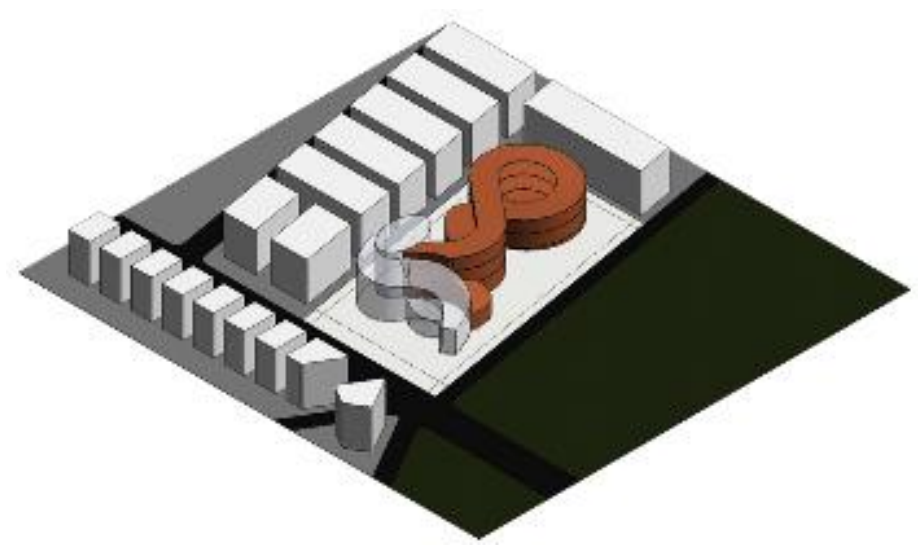

Gambar 13. Massa bangunan sisi belakang Sumber: Penulis, 2021

Hasil akhir dari massa bangunan galeri edukasi plastik dengan metode perancangan plastis.

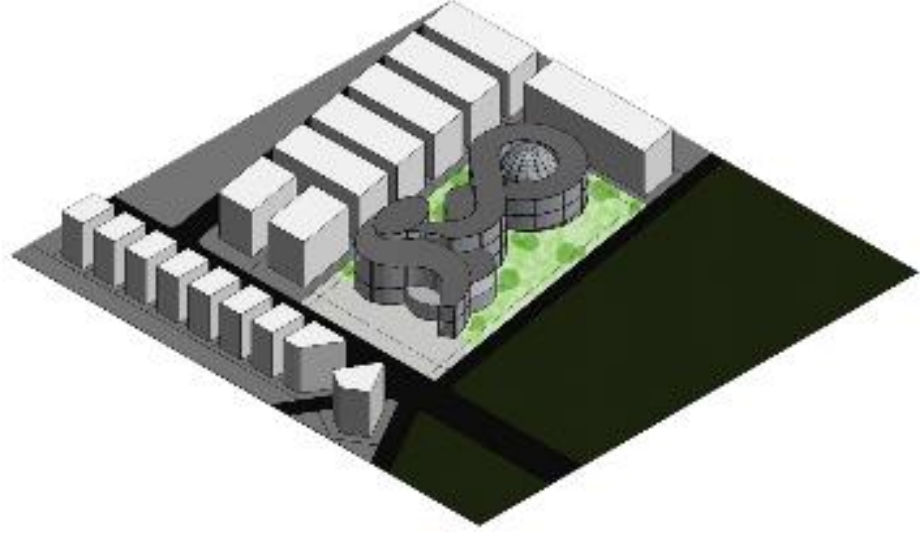

Gambar 14. Hasil akhir massa banguunan

Sumber: Penulis, 2021

Dengan bentuk massa bangunan yang tidak kaku berdasarkan metode perancangan plastis ini akan diterapkan ruang-ruang yang plastis, kegiatan yang plastis, dan penggunaan material plastik. Dengan menunjukan kelebihan-kelebihan plastik melalui metode perancangan plastis ini akan menarik perhatian masyarakat yang datang untuk dapat lebih menghargai plastik dan mampu menghadapi sampah plastik dengan benar.

\section{Pengaplikasian Metode Perancangan Plastis dalam Desain Ruang}

Plastic \& Art Gallery

Plastic Gallery adalah galeri yang menjelaskan kepada pengunjung segala hal mengenai plastic, lalu Plastic Art Gallery adalah galeri yang berisikan karya-karya seni dari plastik. Pengunjung dapat berinteraksi langsung dengan karya seni yang ada sehingga tercipta kegiatan pameran yang aktif. Ruang galeri ini didesain tidak bersiku-siku, terdapat banyak lengkungan, dan terdapat tangga yang di desain melengkung untuk menunjukan sifat plastis dari bangunan. 


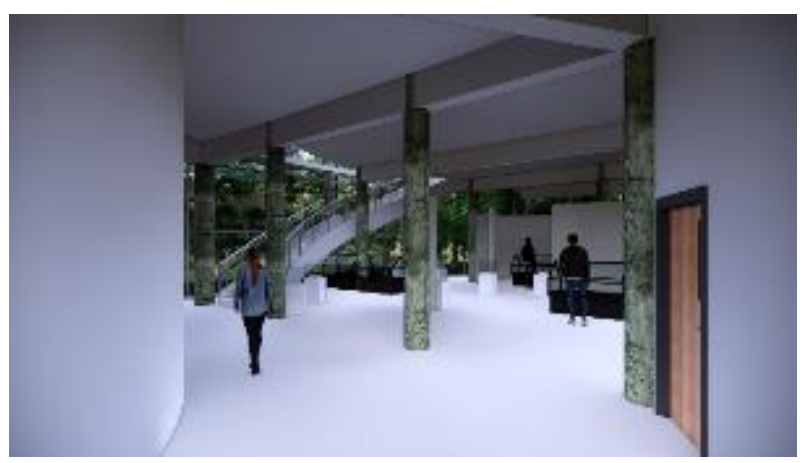

Gambar 15. Plastic \& Art Gallery

Sumber: Penulis, 2021

Plastic Product \& Installation Gallery

Plastic Product Gallery adalah galeri yang berikan produk-produk hasil dari pengolahan plastik, baik produk pengolahan baru ataupun produk hasil daur ulang. Dengan melihat produk-produk plastik ini akan menambah pengetahuan pengunjung akan banyaknya manfaat dari plastik. Lalu untuk Plastic Installation Gallery merupakan instalasi mengenai plastik dimana pengunjung dapat beriteraksi dan mengambil foto disana. Area ini terletak pada bagian spiral bangunan yang sangat memperlihatkan sifat plastis pada pembentuka ruang.

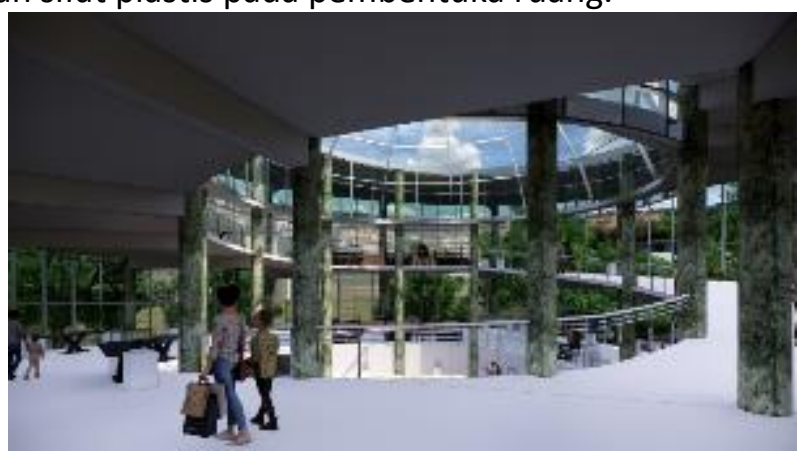

Gambar 16. Plastic Product \& Installation Gallery

Sumber: Penulis, 2021

\section{Plastic Research Gallery}

Plastic Research Gallery adalah galeri yang berisikan hasil-hasil penelitian mengenai plastik hasil dari kompetisi. Hasil-hasil penelitian mengenai plastik ini dipamerkan untuk menarik perusahaan-perusahaan yang bergerak dibidang plastik untuk tertarik dan ingin berkerja sama dengan penemunya. Pada ruang ini didesain menyerupai Plastic Gallery yang tidak bersiku-siku, terdapat banyak lengkungan, dan terdapat tangga melengkung yang menjadi jalan akses vertical dari lantai 1 dan menuju lantai 3.

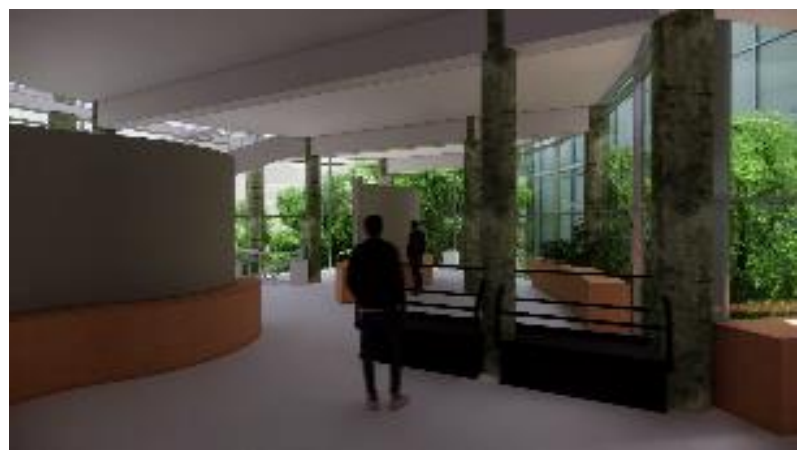

Gambar 17. Plastic Research Gallery

Sumber: Penulis, 2021 


\section{Plastic Audio Visual \& Digital Gallery}

Pada Plastic Audio Visual \& Digital Gallery pameran dilakukan dengan menggunakan teknologi, yaitu dengan layar projektor dan juga layar tablet yang dapat disentuh. Pada galeri ini pengunjung dapat menikmati pameran secara audio visual, dan berinteraksi dengan layar tablet untuk mengakses hal-hal mengenai plastik. Terdapat panel-panel temporer berbentuk melengkung sebagai tempat diletakannya layar tablet yang membuat ruangan tidak terlihat kaku dan dapat berubah posisi peletakannya agar tidak monoton.

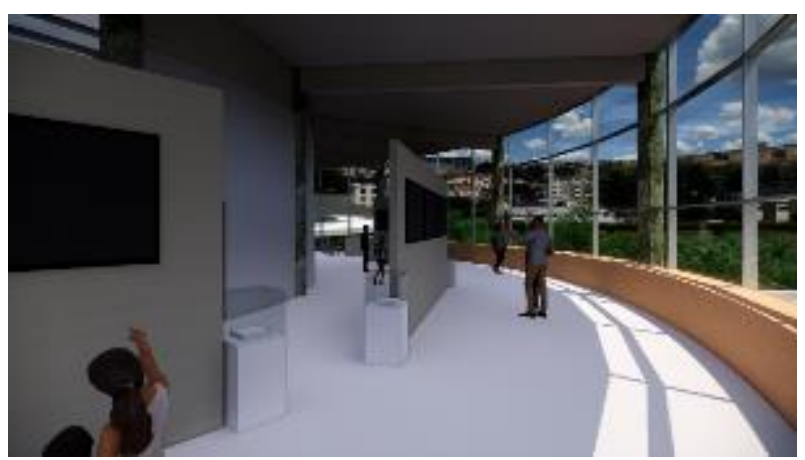

Gambar 18. Plastic Audio Visual \& Digital Gallery

Sumber: Penulis, 2021

Plastic Edu-Park

Plastic Edu-Park merupakan taman edukasi mengenai plastik dimana pengunjung dapat beristirahat dan mempelajari hal-hal mengenai plastik melalui fasilitas-fasilitas taman yang terbuat dari material plastik khusus (Termochromic Plastic) yang dapat berubah warna saat terjadi perubahan suhu. Pada Plastic Edu-Park ini, pengunjung dapat melihat langsung bentuk massa galeri yang melengkung, dan tidak kaku menyesuaikan metode perancangan plastis.

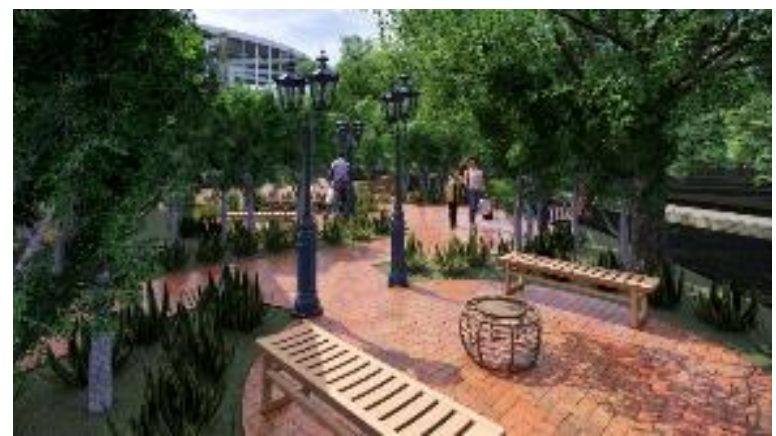

Gambar 19. Plastic Edu-Park

Sumber: Penulis, 2021

\section{KESIMPULAN DAN SARAN}

\section{Kesimpulan}

Perancangan galeri edukasi plastik dengan pendekatan metode perancangan plastis ini merupakan salah satu cara untuk menyadarkan atau mengubah pandangan masyarakat terhadap plastik melalui desain bentuk, ruang, dan kegiatan yang tidak kaku bersama plastik. Masyarakat yang datang akan mulai mengenal kelebihan-kelebihan dari plastik dan lebih paham dalam menangani sampah plastik. Kegiatan masyarakat yang mulai menangani sampah plastik ini akan menjadi kontribusi dalam memerangi sampah plastik dan menciptakan lingkungan yang bersih dan berkelanjutan.

\section{Saran}

Perlu diadakannya suatu pengamatan akan dampak yang dihasilkan oleh galeri edukasi plastik ini terhadap lingkungan masyarakat yang berkunjung, dan apabila dampak yang dihasilkan 
terhadap lingkungan masih buruk atau kurang maka diperlukan perubahan atau penyesuaian terhadap kriteria desain plastis yang diterapkan, namun apabila dampak yang dihasilkan terhadap lingkungan baik atau positif maka proyek serupa dapat dikembangkan pada daerah lainnya untuk menularkan dampak-dampak baik terhadap lingkungannya.

\section{REFERENSI}

Adiwibowo, S. (2007). Ekologi Manusia. Fakultas Ekologi Manusia - IPB

Azzam. I. R. (2021, Februari 5). Kenya Daur Ulang Plastik Menjadi Batu Bata, Lebih Kuat Daripada Beton. Retrieved from seputartangsel.com: https://seputartangsel.pikiranrakyat.com/ teknologi/pr-141383549/kenya-daur-ulang-plastik-menjadi-batu-bata-lebih-kuat-daripadabeton

Departemen Pendidikan Nasional. (2003). Kamus Besar Bahasa Indonesia. Gramedia Pustaka Utama

Engelsmann, S. (2010). Plastic: In Architecture and Construction. Walter de Gruyter GmbH

Gambar 'Bentuk yang plastis', 'Kegiatan yang plastis'. (diakses 2021). Retrieved from: www.artspace.com

Hendrastianto, Z.A. (2019, Juli 29). Plastik: Pengertian, Sejarah, Jenis, Proses Pembuatan, dan Bahan Baku. Retrieved from Foresteract: https://foresteract.com/plastik

Herman, S. (2013). Extreme Bricks. Michael O'Mara

Higgin, C. (2012, Oktober 6). What People in The '50s and '60s Thought Houses Would Look Like in 1986. Retrieved from mentafloss: https://www.mentalfloss.com/article/12908/insidemonsantos-house-future-1957

Jørgensen, S. E. (2009). Ecosystem Ecology. Elsevier.

Kemendikbud. (2021, Februari 16). Kamus Besar Bahasa Indonesia (KBBI). Retrieved from KBBI: https://kbbi.web.id/ekologi

Larasati, M.D. (2017, November 21). Limbah: Pengertian, Jenis, Dampak, dan Pengelolaan. Retrieved from Foresteract.com: https://foresteract.com/limbah-pengertian-jenis-dampakdan-pengelolaan

Prasetyo. B. (2014, Februari 2). InSWA: Saatnya Gunakan Plastik Ramah Lingkungan. Retrieved from Tribunnews.com: https://www.tribunnews.com/iptek/2014/02/02/inswa-saatnyagunakan-plastik-ramah-lingkungan

PT. Impact Pratama Industri. (2019). Mengenal Atap Polycarbonate, Atap Transparan dengan Berbagai Kelebihan. Retrieved August 27, 2019, from https://www.impackpratama.com/mengenal-atap-polycarbonate-dan-kelebihannya

Rahmat. R. (2016, Oktober 20). Dampak Plastik Terhadap Lingkungan. Retrieved from Indonesia Environment \&Energy Center: https://environment-indonesia.com/dampak-plastikterhadap-lingkungan

Richardson, A. (2009, Maret 15). ETFE: Why this Building Material is Gaining Popularity. Retrieved from Architen: https://www.architen.com/articles/etfe-the-new-fabric-roof

Septyan, A.R. (2019, Juni 7). Sampah: Pengertian, Jenis, Penyakit, Energi, dan Dampak Buruk. Retrieved from Foresteract.com: https://foresteract.com/sampah

Steiner, F. (2016). Human Ecology. Island Press

Gambar 'Plastic Bricks'. (Diakses 2021). Retrieved from: www.preciousplastic.com Gambar 'Plastic Paving Block'. (Diakses 2021). Retrieved from: www.joyaplastica.com Gambar 'Plastic Tiles', 'Plastic Sheets'. (Diakes 2021). Retrieved from: www.instructables.com Gambar 'Ruang yang plastis'. (diakses 2021). Retrieved from: www.art-sheep.com 